\title{
Pelatihan Pemanfaatan Digital Marketing Untuk Usaha Keripik Tempe
}

\author{
Nyoman Ayu Nila Dewi ' ${ }^{1}$ Made Satria Wibawa ${ }^{2}$, \\ I Wayan Rupika Jimbara 3, I Putu Hengky Purnama Ariwijaya 4 , \\ I Nyoman Fery Pramana ${ }^{5}$
}

\author{
1, 2, 3, 4, 5, Insitut Teknologi dan Bisnis STIKOM Bali \\ 1'nila@stikom-bali.ac.id; ${ }^{2}$ satria.wibawa@stikom-bali.ac.id; ${ }^{3}$ rupika@stikom-bali.ac.id
}

\begin{abstract}
Abstrak
Kegiatan pengabdian masyarakat ini akan melibatkan salah satu industri rumah tangga pengolah keripik tempe. Keripik tempe yang diproduksi memiliki 3 rasa yaitu original, embe dan caramel. Mitra memulai usaha keripik tempe pada awal tahun 2020. Produksi keripik tempe dibantu oleh 2 orang karyawan dan pemilik usaha ini bernama lbu Riska, pendapatan perbulan saat ini berkisar antara Rp $900.000-\mathrm{Rp}$ 1.200.000. Permasalahan mitra saat ini dari aspek produksi adalah mitra memiliki keterbatasan alat produksi sehingga mitra tidak dapat menerima pemesanan lebih dari kapasitas alat yang dimiliki, waktu pengerjaan produksi membutuhkan waktu 6 jam pengerjaan dengan menggunakan alat manual dan keterbatasan alat produksi. Permasalahan pada aspek pemasaran adalah keterbatasan pengetahuan mitra dalam menggunakan media sosial sebagai alat promosi untuk produk yang dihasilkan. Permasalahan berikutnya adalah mitra belum memiliki desain brand identity yang menarik dan mudah dipasarkan oleh mitra. Dari permasalahan tersebut solusi yang dapat diberikan adalah peningkatan jumlah alat produksi agar dapat mengurangi waktu produksi dan menambah jumlah produksi. Aspek pemasaran akan memberikan pelatihan Instagram dan facebook untuk memperluas pemasaran produk. Memberikan pelatihan pembuatan brand identity produk keripik tempe. Tim pelaksana dalam kegiatan pengabdian ini berjulah 5 orang dan 2 orang peserta pengabdian. Tujuan dari kegiatan pengabdian ini adalah peningkatan jumlah produksi, informasi produk lebih luas dan peningkatan pengetahuan mitra terhadap pemanfaatan penggunaan teknologi. Hasil dari kegiatan pengabdian ini menghasilkan brand identity dan pemasaran produk melalui instagram for bisnis.
\end{abstract}

Kata Kunci: tempe, pemasaran, digital marketing, pengabdian masyarakat, brand identity

\section{Pendahuluan}

Tempe adalah salah satu makanan asli dari Indonesia, yang berasal dari fermentasi kedelai. Tempe menjadi makanan sehari hari yang dikonsumsi oleh hampir seluruh masyarakat Indonesia. Seiring dengan perkembangan zaman yang lebih modern makanan yang berasal dari bahan dasar tempe sudah banyak muncul di masyarakat mulai dari tempe. Salah satu alasan munculnya berbagai olahan tempe adalah mudah didapatkannya bahan dasar berupa tempe (Saputra et al., 2020; Suparjo \& Hariastuti, 2017). 
Namun saat ini tahu dan tempe sudah banyak yang menembus pasar swalayan, mall dan pasar modern lainnya. Bahkan sudah ada yang mengekspor tempe dan tahu ke luar negeri dan membuka cabang produksi dan pemasaran disana. Melihat besarnya pasar yang masih tersedia, dan juga peluang peningkatan usaha menjadi lebih besar sebagai upaya meraih taraf hidup yang lebih baik, menjadi alasan kuat kegiatan pendampingan UKM ini dilakukan (Kurniawati et al., 2019). Mitra dalam kegiatan pengabdian ini adalah olahan tempe menjadi keripik tempe dengan beraneka rasa yaitu: keripik tempe original, keripik tempe caramel, keripik tempe sambal embe.

Usaha ini ditekuni oleh mitra mulai dari bulan April 2020, walaupun usaha ini dapat dikatakan baru namun pemesanan untuk keripik tempe tersebut mengalami selalu mengalami peningkatan. Mitra dalam kegiatan ini adalah lbu Riska mitra merupakan salah satu pekerja yang mengalami dampak dari wabah covid 19, dimana sebelumnya mitra bekerja di salah satu perusahaan swasta yang bergerak dibidang makanan dan mengirimkan makanan ke hotel dan villa. Kondisi tersebut yang membuat mitra untuk memulai usaha keripik tempe, proses produksi dibantu oleh 2 orang keluarga yang terlibat langsung dalam proses produksi dan pengiriman pesanan. Proses produksi dimulai dari mempersiapkan bahan baku yaitu tempe yang di beli langsung dari tempat produksi tempe agar mendapatkan harga yang cukup murah untuk dapat menekan harga jual produk. Proses selanjutnya yaitu melakukan pemotongan tempe dengan alat tradisional yaitu pisau yang digunakan untuk memotong tempe sesuai dengan ukuran keripik.

Namun proses tersebut membutuhkan waktu yang cukup lama karena irisan yang dibutuhkan cukup tipis agar mendapatkan hasil yang maksimal.Dari proses pemotongan,proses menjemur, proses memberikan rasa dan sampai pengemasan membutuhkan waktu produksi sekitar 6 jam proses produksi. Hal ini yang menyebabkan permasalahan dalam proses produksi yaitu waktu produksi yang cukup lama sehingga mitra memiliki keterbatasan dalam menerima pemesanan. Permasalahan berikutnya adalah peralatan produksi yang digunakan mitra masih sangat tradisional dan keterbatasan alat produksi seperti pemotongan menggunakan pisau, penjemuran tempe menggunakan 1 tray yang menyebabkan mitra tidak dapat menjemur melebihi kapasitas tray tersebut. Pengolahan rasa masih menggunakan cara tradisional membutuhkan waktu yang lama untuk memproses 3 rasa varian tempe.

Proses pemasaran mitra memanfaatkan media sosial seperti WA dan Instagram namun hal tersebut belum cukup maksimal seperti penggunaan Instagram masih menggunakan Instagram personal belum memanfaatkan penggunaan Instagram bisnis hal ini karena kurang nya pemahaman mitra.

Pencatatan keuangan masih menggunakan perekapan tradisional Harga keripik tempe kisaran Rp.12.000- Rp 17.000, setiap rasa memiliki harga yang berbeda. Pendapatan mitra dalam 1 bulan berkisar antara Rp 900.000 - Rp 1.200.000 per bulan. Adapun kondisi mitra seperti pada gambar dibawah ini. 

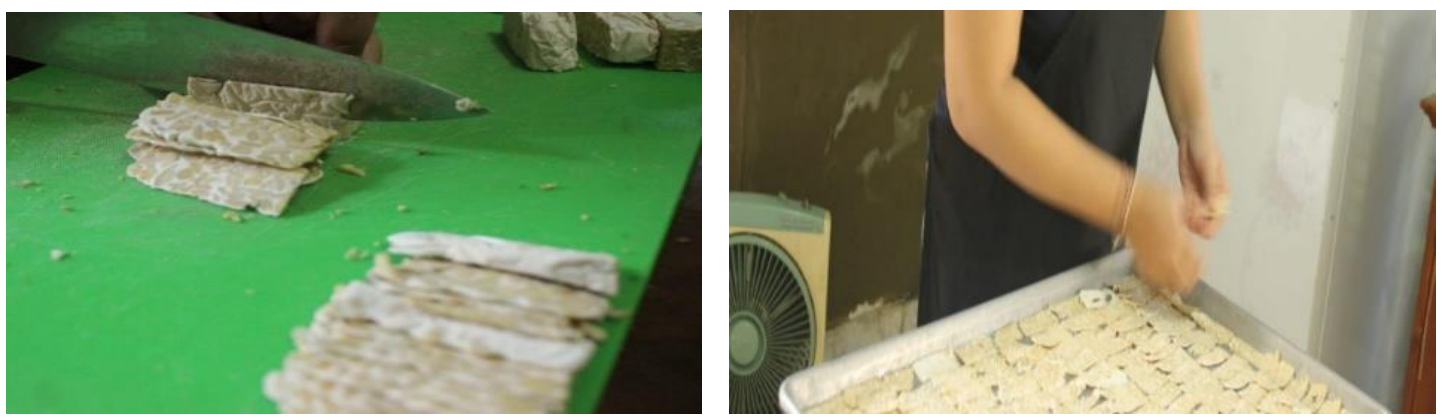

Gambar 1. Proses Produksi keripik tempe

Gambar 1 merupakan kondisi proses produksi beserta alat produksi yang digunakan oleh mitra, dan analisis situasi mitra tergambarkan pada tabel 1 seperti dibawah ini:

Tabel 1. Analisis Situasi

\begin{tabular}{|c|c|c|c|}
\hline No & Uraian & Mitra & Keterangan \\
\hline 1 & Kondisi produksi mitra & $\begin{array}{l}\text { 1. Minimnya jumlah alat produksi. } \\
\text { 2. Beberapa proses produksi } \\
\text { masih menggunakan cara } \\
\text { manual. }\end{array}$ & $\begin{array}{l}\text { Minimnya pengetahuan } \\
\text { mitra tentang } \\
\text { pemanfaatan teknologi } \\
\text { serta pemanfaatan waktu } \\
\text { produksi. }\end{array}$ \\
\hline 2 & Kondisi pemasaran mitra & $\begin{array}{l}\text { 1. Pemasaran melalui konsumen } \\
\text { ke konsumen. } \\
\text { 2. Pemasaran menggunakan } \\
\text { whatsapp }\end{array}$ & $\begin{array}{l}\text { Minimnya pengetahuan } \\
\text { mitra tentang } \\
\text { penggunaan teknologi } \\
\text { secara maksimal. }\end{array}$ \\
\hline 3 & Jumlah produksi mitra per hari & 350 gram /hari & $\begin{array}{l}\text { Jumlah pemesanan } \\
\text { terbatas setiap harinya } \\
\text { karena minimnya jumlah } \\
\text { peralatan yang dimiliki }\end{array}$ \\
\hline
\end{tabular}

Dari permasalahan yang telah diuraikan permasalahan yang menjadi prioritas adalah:

a. Aspek produksi keripik tempe dimana mitra masih menggunakan alat tradisional seperti pisau potong, keterbatasan alat produksi seperti tray yang digunakan untuk menjemur keripik tempe. Alat pengolahan bumbu masih terbatas menggunakan alat tradisional.

b. Aspek pemasaran masih belum optimal dimana mitra memasarkan produk dari konsumen ke konsumen dan melalui whatsapp.

\section{Metode Pelaksanaan}

Kegiatan pengabdian ini dilaksanakan secara online untuk pelatihan pemasaran dan brand identity. Adapun jarak antara mitra dan tim pengusul adalah 7,7 km. Lokasi mitra berada di JI.Pidada VII dan lokasi tim pengusul berada di ITB STIKOM Bali dengan jarak tempuh 14 menit dengan menggunakan kendaraan roda 4. Adapun metode pelaksanaan kegiatan pengabdian seperti pada gambar 2 . 


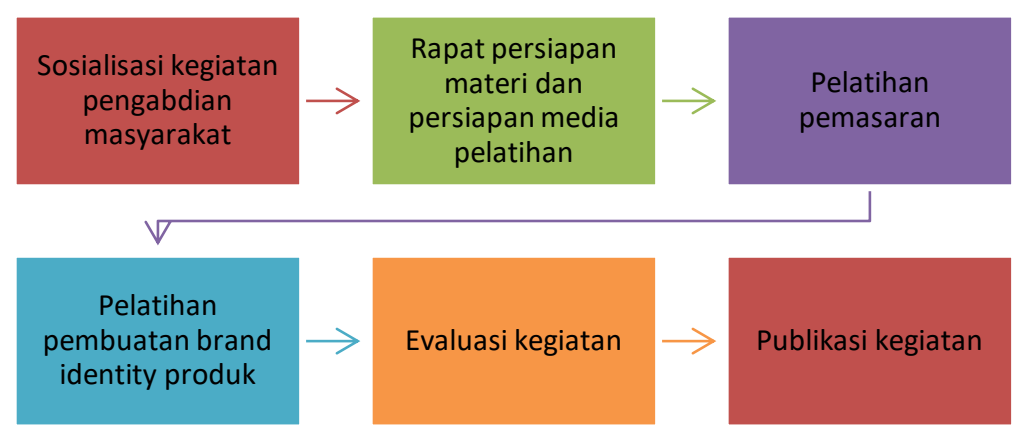

Gambar 2. Rencana Kegiatan

Gambar diatas menjelasakan tahapan yang akan dikerjakan dalam kegiatan pengabdian masyarakat dimulai dari tahap:

1. Sosialisasi kegiatan

Kegiatan ini merupakan tahap sosialisasi kegiatan pengabdian ke mitra untuk memberikan penjelasan mengenai kegiatan yang akan dilaksanakan, manfaat kegiatan serta penentuan jadwal kegiatan. Kegiatan pengabdian ini $80 \%$ akan dilakukan secara daring dengan menggunakan media zoom.

2. Rapat persiapan materi dan persiapan media pelatihan

3. Pelatihan pemasaran

Pelatihan pemasaran menggunakan Instagram dan facebook untuk dapat menyebarkan informasi lebih luas.

4. Pelatihan pembuatan brand identity produk dengan memberikan pelatihan pembuatan brand identity untuk produk yang dihasilkan seperti merek maupun logo produk.

5. Evaluasi kegiatan

Evaluasi kegiatan merupakan tahap akhir yang akan dilakukan yaitu dengan melakukan evaluasi pemahaman serta peningkatan produksi mitra sebelum diberikan pelatihan dan sesudah diberikan pelatihan.

6. Publikasi kegiatan

\section{Hasil dan Pembahasan}

\section{Sosialisasi Kegiatan ke Mitra}

Sosialisasi kegiatan pengabdian masyrakat selalu dilakukan di awal kegiatan untuk menginformasikan kepada mitra tentang pentingnya kegiatan pengabdian masyarakat. Kegiatan ini dilakukan oleh tim pelaksana pengabdian masyarakat untuk sosialisasi kegiatan pengabdian, sosialisasi ini menyampaikan tujuan dari kegiatan yang akan dilaksanakan serta menentukan kesepakatan kegiatan yang akan dilaksanakan.

\section{Pelatihan Pemasaran}

Kegiatan pelatihan pemasaran dilakukan untuk meningkatkan informasi penyebaran produk yang di produksi. Pelatihan pemasaran dengan pemaksimalan penggunaan 


\section{Madaniya \\ ISSN 2721-4834}

instagram dalam pemasaran produk. Berikut hasil kegiatan pemasaran yang dilakukan adalah sebagai berikut:

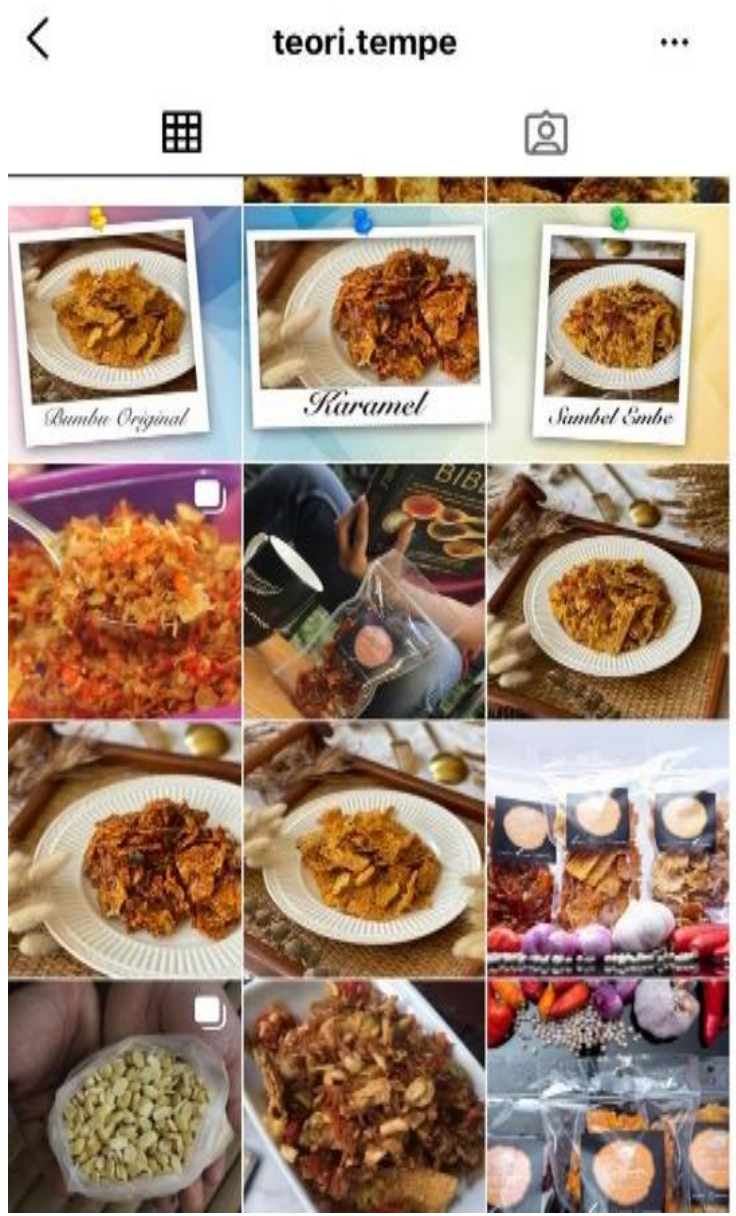

Gambar 3. Instagram teori tempe

Gambar diatas merupakan instagram dari usaha keripik tempe yang diproduksi. Penggunaan instagram bisnis memberikan gambaran tentang informasi secara data terkait dengan hal apa yang lebih disukai pelanggan, jenis kelamin pelanggan yang sering melihat promosi iklan maupun pemasaran yang dilakukan serta waktu-waktu yang dapat digunakan untuk memasarkan produk. Kegiatan pelatihan pemasaran ini memberikan wawasan kepada mitra langkah-langkah yang dilakukan untuk mengubah akun instagram mitra ke instragram bisnis. Adapun materi yang diberikan sebagai berikut: 


\section{Langkah Pertama dengan memilih menu setting}

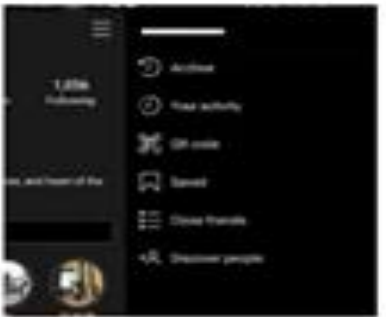

Pada akun masing masing dapat melihat menu setting segerti pada tampilan berikut dan pilith accoun:

Gambar 4. Materi pelatihan pemasaran

Berikut merupakan hasil dari pemasaran menggunakan instagram bisnis, pada bagian produk yang di promosikan ada menu view insights yang dapat digunakan untuk melihat aktifitas pengunjung.

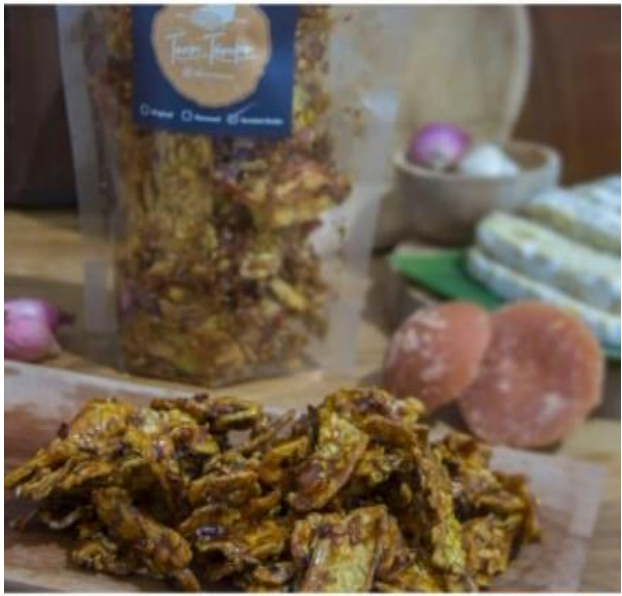

View Insights
Promote

ఐ

BDy Liked by bp_linangdita and 10 others makanasikdibali Ad yg baru nie, buat km yg doyan banget ngemil, its @teori.tempe... more

Gambar 5. Instagram bisnis

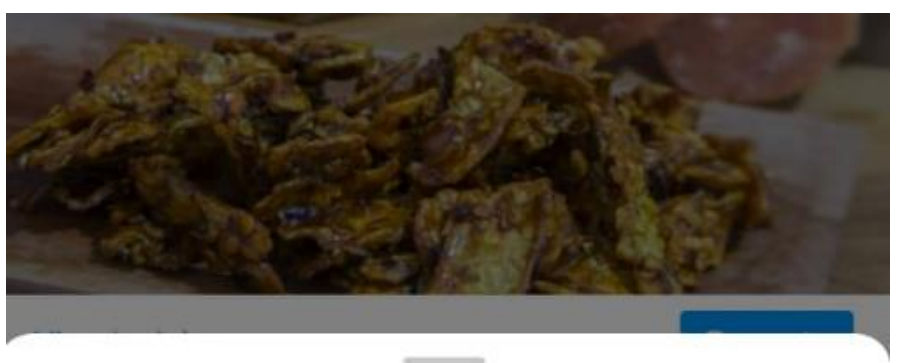

Messaging-related insights, such as shares and replies, may be lower than expected due to new privacy rules in Europe. Learn More

11
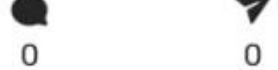

0

5

180

Profile Visits

Reach

Gambar 6. Instagram insights

Setelah tampilan diatas maka muncul tampilan informasi terkait dengan postingan produk yang telah di promosikan. Tampilan diatas memberikan informasi bahwa dari postingan foto yang telah dipasarkan pada instagram bisnis maka hasilnya ada 11 pengunjung yang memberikan like, tidak ada komentar terkait postingan tersebut, tidak ada share terkait postingan tersebut, tidak ada save terkait postingan tersebut. Terdapat 5 pengunjung yang melihat postingan tersebut dan 180 pengunjung yang masuk namun melewati postingan tersebut. 
Tujuan dari kegiatan pelatihan pemasaraan pemanfaatan instagram bisnis adalah :

1. Dengan akun instagram bisnis kebutuhan bisnis lebih profesional, dimana akun tersebut terpisah dari akun personal untuk manajemen posting, informasi kontak dan kebutuhan lainnya.

2. Akses ke instagram insight, hal ini digunakan untuk menambah wawasan dalam pengembangan akun instagram. Manfaat menggunakan instagram insight adalah untuk jangkauan promosi lebih luas, produk yang di promosikan menjadi konten populer, terlihat data tingkat keterlibatan konsumen, konten populer, tingkat pertumbuhan follower dan waktu interaksi terbaik. Dari data yang akan didapat pada instagram, insight terlihat banyak hal yang nantinya dapat dioptimalkan dalam memasarkan produk.

3. Dapat melakukan posting di waktu terbaik follower

4. Dapat melakukan analisa karakter follower

5. Strategi konten marketing

6. Strategi promosi yang terarah

7. Mendorong pertumbuhan follower yang optimal

8. Calon pembeli dapat menghubungi dengan mudah

9. Informasi terkait instagram dengan kategori bisnis akan muncul untuk akun instagram yang sudah beralih ke instagram bisnis(Susanti, 2020).

Selain memasarkan pada akun @teori.tempe produk juga dipasarkan pada akun-akun instagram lainnya yang mengelola pemasaran produk makanan seperti @masakasikbali dan @foodsbaliculinary dan akun instagram lainnya. Kegiatan ini bertujuan untuk menyebarkan lebih banyak informasi produk yang ingin dipasarkan. Hal ini merupakan langkah atau stategi lain yang ingin dilakukan tim dan mitra agar dapat mempercepat penyebaran informasi dan melihat respon dari konsumen. Adapun hasil kegiatan dengan pemasaran di akun promosi makanan lainnya seperti pada gambar berikut:
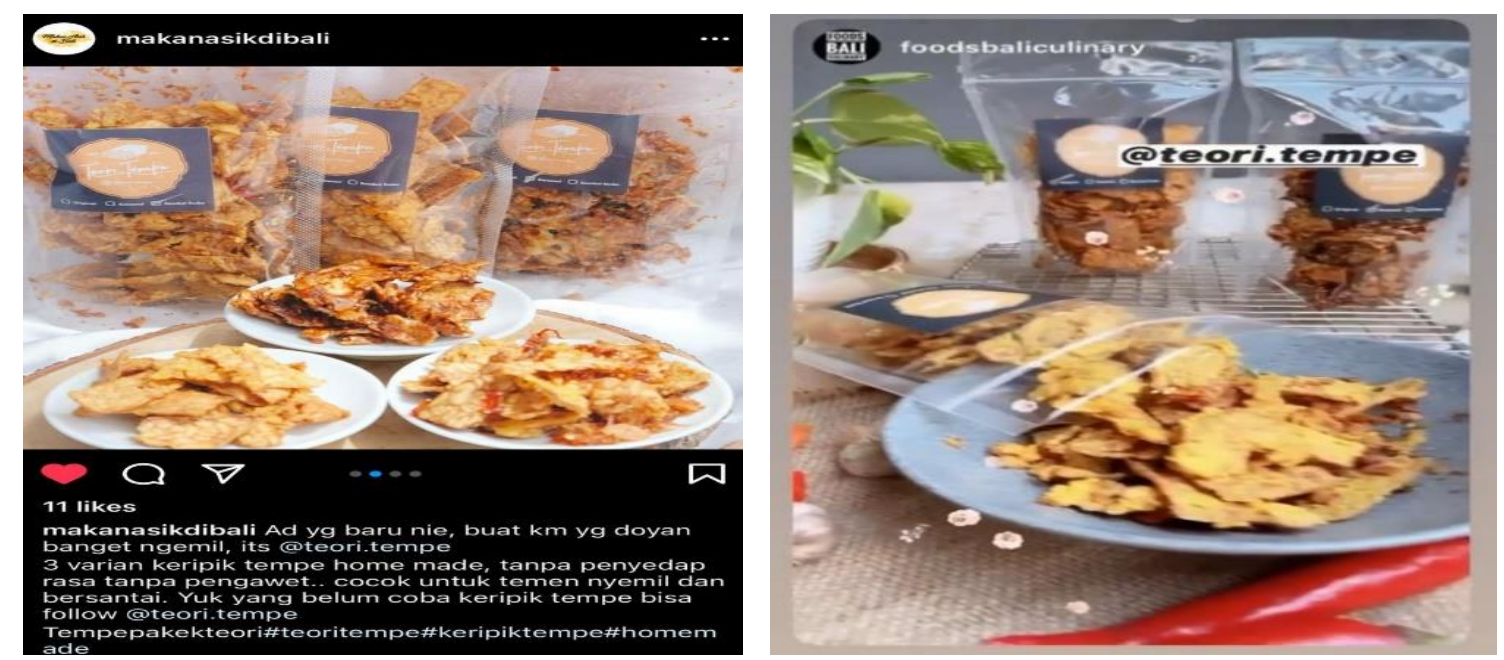

Gambar 7. Promosi pada akun instagram lain 
Vol. 2, No. 3, Agustus 2021

ISSN 2721-4834

\section{Pelatihan Pembuatan Brand Identity}

Kegiatan pengabdian masyarakat selanjutnya adalah pelatihan brand identity, dalam kegiatan ini tim pelaksana dan mitra sepakat untuk menggunakan canva dalam membuat brand identity dengan alasan dapat dengan mudah digunakan oleh mitra. Kegiatan pelatihan pengabdian masyarakat ini berlangsung selama 2 hari kegiatan dengan diawali pelatihan materi dengan memberikan langkah-langkah dalam membuat brand identity yang selanjutnya tim beserta mitra membuat desain logo yang akan digunakan dalam produk. Kegiatan pelatihan ini berlangsung secara online melihat situasi dan kondisi pandemi seperti ini seluruh kegiatan pelatihan dilakukan secara daring. Adapun materi kegiatan yang diberikan adalah sebagai berikut:

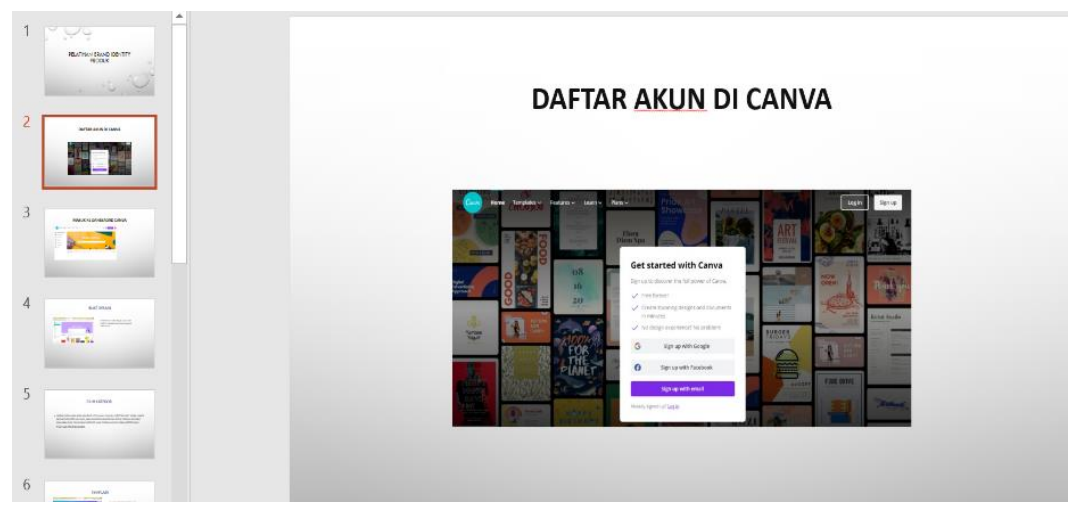

Gambar 8. Materi pelatihan brand identity

Hasil dari kegiatan pelatihan brand identity ini meghasilkan desain logo yang dapat digunakan di produk yang dipasarkan. Adapun hasil desain brand identity sebagai berikut:
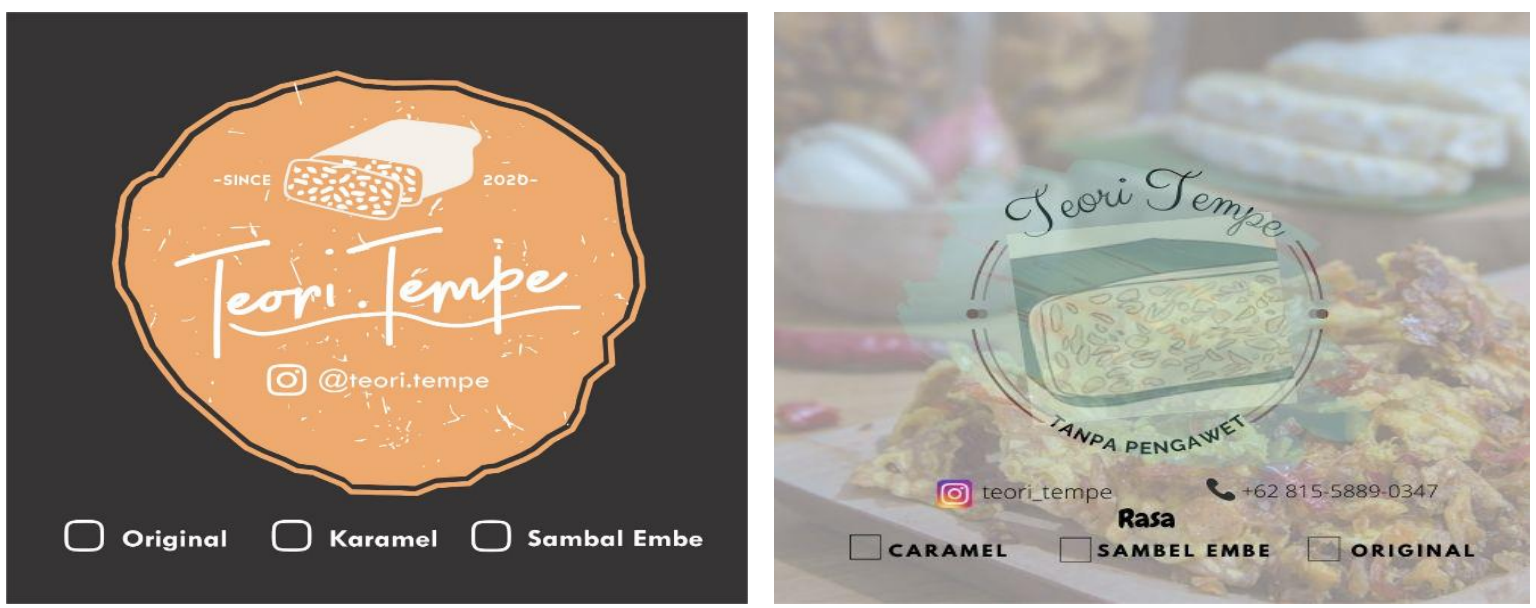

Gambar 9. Logo produk

Dari kegiatan tersebut menghasilkan 2 desain brand identity yang akan digunakan untuk label produk. Label produk mencantumkan informasi nama produk, nama akun instagram yang dapat digunakan oleh konsumen varian rasa yang diproduksi dan digunakan untuk menentukan rasa di masing-masing kemasan. Luaran kegiatan dalam 
pelaksanaan pengabdian masyarakat ini dikelompokkan berdasarkan kegiatan yang telah dilakukan, adapun hasil dari luaran tersebut adalah sebagai berikut:

\section{Kegiatan Pelatihan Pemasaran}

Kegiatan luaran dalam pengabdian masyarakat ini adalah jumlah produksi keripik tempe. adapun data jumlah produksi setiap bulan seperti pada tabel dibawah ini:

Tabel 2. Jumlah produksi

\begin{tabular}{lrrr}
\hline $\begin{array}{l}\text { Produksi keripik } \\
\text { tempe }\end{array}$ & Desember 2020 & Januari 2021 & Pebruari 2021 \\
\cline { 2 - 4 } & 178 bungkus & 240 bungkus & 191 bungkus \\
\hline
\end{tabular}

\section{Kegiatan Pelatihan Brand Identity}

Kegiatan luaran pelatihan brand identity adalah jumlah followers di instagram teori tempe. Dari hasil kegiatan pelatihan brand identity untuk jumlah followers adalah sebagai berikut:

Tabel 3. Jumlah Followers

\begin{tabular}{lrcc}
\hline $\begin{array}{l}\text { Jumlah Followers } \\
\text { Instagram }\end{array}$ & Desember 2020 & Januari 2021 & Pebruari 2021 \\
\cline { 2 - 4 } & 230 followers & 233 followers & 234 followers \\
\hline
\end{tabular}

\section{Kesimpulan}

Kesimpulan dari kegiatan pengabdian ini adalah permasalahan mitra terkait dengan pemasaran produk sudah dapat diselesaikan dengan melakukan pemasaran pada akunakun instagram lain yang khusus penyediakan pelayanan promosi usaha makanan serta memaksimalkan penggunaan akun instagram ke akun bisnis yang bertujuan untuk dapat meningkatkan strategi pemasaran. Kegiatan selanjutnya yang telah diberikan adalah pelatihan brand identity produk yaitu memberikan pelatihan cara membuat brand identity dengan menggunakan canva untuk lebih mudah digunakan oleh mitra. Brand identity saat ini telah memberikan informasi nama usaha serta informasi yang dapat dihubungi oleh konsumen.

\section{Ucapan Terimakasih}

Terimakasih kami ucapkan kepada Bagian LPPM yang telah membantu dokumendokumen dalam kegiatan pengandian yang telah dilaksanakan. Terimakasih juga kami ucapkan kepada mitra yang telah memberikan waktu dan menyediakan tempat untuk keberlangsungan kegiatan pengabdian masyarakat ini.

\section{Referensi}

Kurniawati, T., Sa'ida, N., Wahono, W., \& Hermoyo, P. (2019). Peningkatan Produktivitas Pengusaha Tempe. Aksiologiya: Jurnal Pengabdian Kepada Masyarakat, 2(2), 181.

Saputra, R., Ardhiani, L. N., \& ... (2020). Digital Marketing sebagai Upaya Pemberdayaan Masyarakat di Kabupaten Batang. ... Masyarakat UNDIP 2020, 352-356. 
Vol. 2, No. 3, Agustus 2021

ISSN 2721-4834

Suparjo, \& Hariastuti, N. L. P. (2017). Pendampingan Pengabdian Kepada Masyarakat Untuk UKM Produk Tempe Di Kapasjaya. Jurnal Pengabdian LPPM Untag Surabaya, 2(3), 1-9.

Susanti, E. (2020). PELATIHAN DIGITAL MARKETING DALAM UPAYA PENGEMBANGAN USAHA BERBASIS TEKNOLOGI PADA UMKM DI DESA SAYANG KECAMATAN JATINANGOR. Sawala : Jurnal Pengabdian Masyarakat Pembangunan Sosial, Desa Dan Masyarakat, 1(2), 36. 